\title{
Kecerdasan Spiritual Anak; \\ Dimensi, Urgensi dan Edukasi
}

\author{
Siti Sofiyah \\ Sekolah Tinggi Agama Islam YPBWI Surabaya \\ Email: sitisofiyah8786@gmail.com
}

\begin{abstract}
Abstrak
Permasalahan pokok penelitian ini adalah bagaimana membina kecerdasan spiritual anak dalam keluarga. Adapun tujuan penulis mengangkat topik ini adalah untuk mengungkap peran orang tua dalam membina kecerdasan spiritual anak dalam lingkungan keluarga. Berdasarkan hasil penelitian kualitatif ini, dapat diambil kesimpulan bahwa kecerdasan spiritual adalah sesuatu yang berkaitan dengan ruh, semangat dan jiwa religius serta memiliki pola pemikiran tauhid (integralistik) serta berprinsip hanya karena Allah. Secara umum, ada dua faktor utama yang mempengaruhi kecerdasan yaitu; figur genetik atau bawaan dan faktor lingkungan yaitu lingkungan rumah, kecukupan nutrisi, interfensi dini dan pendidikan di sekolah. Maka, langkah-langkah yang harus diperhatikan orang tua dalam pembinaan kecerdasan spiritual pada anak antara lain: melibatkan anak dalam kegiatan-kegiatan keagamaan, bacakan puisi-puisi atau lagu-lagu yang spiritual dan inspirasional, bawa anak untuk menikmati keindahan alam, ikut sertakan anak dalam kegiatan-kegiatan sosial dan jadilah cermin positif. Penelitian ini dapat dijadikan sebagai acuan bagi orang tua, pendidik, dan penanggungjawab pendidikan pada umumnya dalam upaya menanamkan kecerdasan spiritual sejak dini pada anak.
\end{abstract}

Kata Kunci: Kecerdasan Spiritual, Pendidikan Islam, Keluarga

\section{Pendahuluan}

Dalam rangka mencapai pendidikan, Islam mengupayakan pelatihan seluruh potensi manusia secara serasi serta seimbang menggunakan terbinanya seluruh potensi manusia secara sempurna diperlukan dia dapat melaksanakan fungsi pengabdiannya menjadi khalifah pada muka bumi. buat bisa melaksanakan pengabdian tadi harus dibina semua potensi yang dimiliki yaitu potensi spiritual, kecerdasan, perasaan dan kepekaan. Potensi-potensi itu sesungguhnya adalah kekayaan dalam diri manusia yang amat berharga. ${ }^{1}$

Peranan orang tua sangat berpengaruh sekali pada mendidik anakanaknya terutama sekali pada pada pendidikan agama Islam. Anak ialah

${ }^{1}$ Abuddin Nata, Filsafat Pendidikan Islam (Jakarta : Logos Wacana Ilmu, 1997), 51. 
bahagian dari masyarakat yang dipundaknya terpikul beban pembangunan dimasa mendatang, dan pula menjadi generasi penerus berasal yang tua-tua, maka berasal itu orang tua wajib lebih memperhatikan serta selalu membimbing dan mendidik menggunakan baik, sehingga tercapailah baginya kebahagiaan global serta kebahagiaan akhirat.

Pada dasarnya manusia diciptakan dengan membawa unsur-unsur kecerdasan. Awalnya kecerdasan yang dipahami banyak orang hanya merupakan kecerdasan intelejensi (intelegency quotient), sesuai dengan perkembangan pengetahuan manusia, maka ditemukan tipe kecerdasan lainnya melalui penelitian-penelitian empiris dan longitudinal oleh para akademisi dan praktisi psikologi, antara lain yaitu kecerdasan spiritual (spiritual quotient). Bentuk kecerdasan ini digunakan untuk meraih kesuksesan dalam bekerja dan kehidupan. Kesuksesan paripurna adalah jika seseorang mampu memahami dengan baik kecerdasan spiritual, serta mengaplikasikannya dalam kehidupan. Selanjutnya kecerdasan spiritual yang merupakan kecerdasan memberi arti pada hidup akan mendorong pembuatan tujuan yang mulia, dan apabila dikaitkan dengan seni mengelola keuangan pribadi maka kecerdasan spiritual akan mendorong penetapan tujuan dari mengelola keuangan yang baik dan benar sehingga berpeluang terhindar dari cara akumulasi keuangan yang bias. Selain itu, kecerdasan spiritual juga akan menimbulkan sikap-sikap positif seperti tanggung jawab, kemandirian, kejujuran dan optimalisasi kebebasan keuangan akan lebih terbuka peluangnya.

Ketiadaan kecerdasan spiritual akan mengakibatkan hilangnya kenyamanan bathin serta di akhirnya akan mengakibatkan hilangnya kebahagiaan pada diri orang tadi. Besarnya kecerdasan ruh lebih besar dari pada kecerdasan hati dan kecerdasan otak atau kecerdasan ruh cendrung mencakup kecerdasan hati serta kecerdasan otak. ${ }^{2}$ Kecerdasan spiritual artinya kecerdasan jiwa. ia bisa membantu manusia menyembuhkan dan membentuk dirinya secara utuh. Kecerdasan spiritual ini berada pada bagian diri yang paling pada yang bekerjasama pribadi dengan kearifan serta pencerahan yang dengannya manusia tak hanya mengakui nilai-nilai yang terdapat tetapi manusia secara kreatif menemukan nilai-nilai yang baru.

Secara konseptual kecerdasan spiritual terdiri berasal adonan istilah kecerdasan dan spiritual. Kecerdasan berasal berasal istilah cerdas yaitu sempurna perkembangan nalar budi buat berfikir dan mengerti. Sedangkan spiritual berasal asal istilah spirit yang asal dari bahasa Latin

${ }^{2}$ Dedhi Suharto, Qur'anis Quotient (Jakarta : Yayasan Ukhuwah, 2003), 53. 
yaitu sprites yang berarti nafas. dalam kata terbaru mengacu kepada tenaga batin yang non jasmani mencakup emosi dan karakter. ${ }^{3}$ Dalam kamus psikologi spirit merupakan suatu zat atau makhluk immaterial, umumnya bersifat ketuhanan dari aslinya, yang diberi sifat asal poly ciri ciri manusia, kekuatan, energi, semangat, vitalitas energi disposisi, moral atau motivasi. ${ }^{4}$ Dengan demikian dapat dimaknai bahwa yang dimaksud menggunakan kecerdasan spiritual ialah kemampuan yang tepat asal perkembangan akal budi buat memikirkan hal-hal Di luar alam materi yang bersifat ketuhanan yang memancarkan energi batin untuk memotivasi lahirnya ibadah serta moral.

Menggunakan kecerdasan spiritual berarti memfungsikan kemampuan untuk memberi makna ibadah terhadap setiap perilaku dan kegiatan melalui langkah-langkah dan pemikiran yang bersifat fitrah, menuju manusia yang seutuhnya dan memiliki pola pemikiran integralistik serta berprinsip hanya karena Allah. Sesorang yang memiliki kecerdasan spiritual tinggi adalah orang yang memiliki prinsip dan visi yang kuat, mampu memaknai setiap sisi kehidupan serta mampu mengelola dan bertahan dalam kesulitan dan kesakitan. Kecerdasan spiritual memiliki banyak efek pada kehidupan manusia dan di tempat kerjanya. Para ahli percaya fungsi dan efek kecerdasan spiritual sangat tinggi. Menurut George dalam Rezaei, Kazemi, dan Isfahani yakin aplikasi yang paling penting dari kecerdasan spiritual di tempat kerja meliputi: 1) Menciptakan pikiran yang damai sehingga dapat mempengaruhi efektifitas seseorang; 2) Menciptakan saling pengertian dan memahami; 3) Menciptakan perubahan manajemen. ${ }^{5}$

King, merumuskan empat indikator dalam kecerdasan spiritual, antara lain adalah pemikiran eksistensial yang kritis adalah kemampuan untuk berpikir kritis tentang isu-isu seperti makna, tujuan, eksistensi, kematian, kemampuan untuk menghadapi dengan kesimpulan, kemampuan untuk berpikir tentang isuisu non-eksistensi dari perspektif eksistensial. Selanjutnya, pemaknaan pribadi adalah kemampuan untuk melakukan makna dan tujuan pribadi dalam semua pengalaman materi dan fisik, termasuk kemampuan untuk menciptakan tujuan dalam kehidupan. Kesadaran transedental menjadi bagin integral. Ia adalah

3 Toni Buzan, Kekuatan ESQ: 10 langkah Meningkatkan Kecerdasan Emosional Spiritual, Terj. Ana Budi Kuswandani (Indonesia: Pustaka Delapratosa, 2003, 6.

${ }^{4}$ J.P. Chaplin, Kamus Lengkap Psikologi (Jakarta: Rajawali Pers, 1989), 480.

${ }^{5}$ H. Rezaei, A. Kazemi, N. Isfahani, “An Analysis of Spiritual Intelligence Effect on Marketing Performance and Innovation in Sales and Marketing unit (Case Study: Isfahan Mobarakeh Steel Company)", Interdisciplinary Journal of Contemporary Research in Business, Vol. 3, No. 6 (2011): 683-692.

El-Banat Vol. 9. No.2 (2019) 221 
kemampuan untuk mengenali dimensi dan kemampuan keunggulan diri (transformasi internal dan eksternal). Puncaknya adalah Perluasan area kesadaran adalah kemampuan untuk memasuki tingkat spiritualitas yang paling tinggi. ${ }^{6}$ Spiritualitas dalam pengertian yang luas, merupakan hal yang berhubungan dengan spirit. Sesuatu yang spiritual memiliki kebenaran abadi yang berhubungan dengan tujuan hidup manusia, sering dibandingkan dengan sesuatu yang bersifat duniawi dan sementara.

Namun demikian, kecerdasan spiritual juga meliputi adanya kematangan emosional yang ada pada anak. Seorang anak dalam pertumbuhan dan perkembangannya, dalam kehisupan di bawah kontrol orang tua. Ini merupakan kebutuhan yang anak miliki. Oleh karena itu, penanaman kecerdasan spiritual harus dilakukan oleh semua orang tua kepada anak, karena dalam spiritualitas ada kesadaran dan kesatuan dengan orang lain, dan juga kombinasi dari filosofi dasar kita tentang kehidupan, sikap dan praktek. Berdasarkan dari uraian tersebut, penulis tertarik untuk mengkaji kecerdasan spiritual anak dalam frame dimensi, urgensi dan edukasinya yang akan penulis uraikan secara sistematis pada bagian-bagian artikel ini.

\section{Dimensi Spiritualitas Manusia}

Spiritualitas merupakan potensi dari dimensi non-material atau roh manusia. Potensi tersebut seperti intan yang yang belum ter-asah yang dimiliki oleh semua orang. Selanjutnya, tugas setiap oranglah untuk mengenali potensi masingmasing sekaligus menggosoknya hingga berkilau dengan tekad yang besar dan menggunakannya untuk memperoleh kebahagiaan abadi. Spiritualitas, dalam pengertian yang luas, merupakan hal yang berhubungan dengan spirit. Sesuatu yang spiritual memiliki kebenaran abadi yang berhubungan dengan tujuan hidup manusia, sering dibandingkan dengan sesuatu yang yang bersifat duniawi dan sementara. ${ }^{7}$ Individu yang cerdas secara spiritual melihat kehidupan ini lebih agung dan sakral, menjalaninya sebagai sebuah panggilan (vocation) untuk melakukan sesuatu yang unik, menemukan ekstase-ekstase kehidupannya dari pelayanan kepada gagasan-gagasan yang bukan pemuasan diri sendiri, melainkan kepada tujuan luhur dan

\footnotetext{
${ }^{6}$ B. King, "The Influence of Emotional Intelligence on the Service Performance of Casino Frontline Employees", Tourism and Hospitality Research, Vol. 11, No. 1 (2011): 49-66.

${ }^{7}$ K.A. Khavari, Spiritual Intelligence; A Pratictical Guide to Personal Happiness (Canada: White Mountain Publications, 2000).
} 
agung, yang bahkan sering keluar dari dunia ini, bersifat abadi dan eksatologis.

Spiritualitas seseorang dapat dilihat dari hidup mereka lebih baik dan cara-cara baru dalam kehidupan mereka, kesediaan mereka untuk mengambil nilai tertinggi untuk menjadi transendental dan bersikeras diri pada pembuatan hubungan dengan orang lain, dengan cara beralih dari perhatian bahan ke perhatian perhatian nyata. Spiritualitas adalah membangun melibatkan kepentingan pribadi dan perhatian kepada orang lain. Spiritualitas meliputi aspek hal melampaui kepada Allah, memperhatikan diri sendiri, dan orang lain. Menjelaskan bahwa dari perspektif iman, spiritualitas dapat dilihat dari empat hubungan yaitu hubungan ke diri, orang lain, alam atau lingkungan dan untuk daya yang lebih tinggi. Remaja yang menemukan spiritualitas akan mampu membuat penyesuaian diri. $^{8}$

Manusia yang memiliki kecerdasan spiritual dapat memiliki kemampuan bersifat fleksibel, tingkat kesadaran yang tinggi, kemampuan untuk menghadapi dan memanfaatkan penderitaan, kemampuan untuk menghadapi dan melampui rasa sakit, kualitas hidup yang diilhami oleh visi dan nilai-nilai, dan keengganan untuk menyebabkan kerugian yang tidak perlu. Individu yang cerdas secara spiritual melihat kehidupan ini lebih agung dan sakral, menjalaninya sebagai sebuah panggilan untuk melakukan sesuatu yang unik, menemukan ekstase-ekstase kehidupannya dari pelayanan kepada gagasangagasan yang bukan pemuasan diri sendiri, melainkan kepada tujuan luhur dan agung, yang bahkan sering keluar dari dunia ini, bersifat abadi dan eksatologis. Kehidupan menjadi lebih sebagai instrument ketimbang tujuan akhir. ${ }^{9}$

Ary Ginanjar Agustian, mendefinisikan bahwa kecerdasan spiritual merupakan kemampuan untuk memberi makna ibadah di setup perilaku serta aktivitas melalui langkah-langkah serta pemikiran yang bersifat fitrah, menuju manusia seutuhnya (hanif), dan memiliki pola pemikiran tauhid (integralistik) Berta berprinsip hanya karena Allah. ${ }^{10}$ Berarti orang yang cerdas secara spiritual artinya orang yang bisa mengaktualisasikan nilai-nilai llahiah menjadi manifestasi asal aktifitasnya pada kehidupan sehari-hari serta berupaya mempertahankan keharmonisan serta

${ }^{8}$ Lihat, Julia Aridhona, "Hubungan antara Kecerdasan Spiritual dan Kematangan Emosi Dengan Penyesuaian Diri Remaja", Intuisi; Jurnal Psikologi Ilmiah, Vol. 9, No. 3 (2017).

9 M. Japar, "Religiousity, Spirituality and Adolescents Self-Adjustment. International Education Studies, Vol. 7, No. 10 (2014): 66.

${ }^{10}$ Departemen Agama RI, Al-Qur'an dan Terjemahannya (Bandung: Syamil Cipta Media, 2005), 553. 
keselarasan pada kehidupannya, sebagai wujud berasal pengalamannya terhadap tuntutan fitrahnya menjadi makhluk yang mempunyai ketergantungan terhadap kekuatan yang berada di luar jangkauan dirinya yaitu sang Maha Pencipta. Kebutuhan akan spiritual adalah kebutuhan buat mempertahankan keyakinan, mengembalikan keyakinan, memenuhi kewajiban kepercayaan, menyeimbangkan kemampuan intelektual dan emosional yang dimiliki seorang, sebagai akibatnya menggunakan kemampuan ini akan membantu mewujudkan pribadi manusia seutuhnya. Spiritual dalam Islam identik menggunakan kecerdasan ruhaniah yang pada dasarnya tahap pencerdasan ruh ini dapat kita mulai semenjak pra kehamilan, kemudian kita teruskan pada ketika kehamilan, dan kita bangun sejak balita hingga dewasa. Setiap pemeluk kepercayaan yang meyakini eksistensi Allah selaku penciptanya, maka pada dirinya tumbuh spiritualitas tadi.

Menurut Eckersley, kecerdasan spiritual didefinisikan sebagai perasaan intuisi yang dalam terhadap keterhubungan dengan dunia luas didalam hidup kita. ${ }^{11}$ Menurut Ashmos dan Duchon, konsep mengenai kecerdasan spiritual dalam hubungannya dengan dunia kerja memiliki tiga komponen yaitu kecerdasaan spiritual sebagai nilai kehidupan dari dalam diri, sebagai kerja yang memiliki arti dan komunitas. ${ }^{12}$ Sedangkan, Mccormick, Mitroff, dan Denton dalam penelitiannya membedakan kecerdasan spriritual dengan religiusitas di dalam lingkungan kerja. Religiusitas lebih ditujukan pada hubungannya dengan Tuhan sedangkan kecerdasan spiritual lebih terfokus pada suatu hubungan yang dalam dan terikat antara manusia dengan sekitarnya secara luas. ${ }^{13}$

Dengan kecerdasan spiritual menjadikan manusia yang benar-benar utuh secara intelektual, emosional dan spiritual. Kecerdasan spiritual adalah kecerdasan jiwa. Ia adalah kecerdasan yang dapat membantu manusia menyembuhkan dan membangun diri manusia secara utuh. Selain itu, kecerdasan spiritual memberikan kemampuan untuk membedakan, memungkinkan seseorang untuk memberikan batasan serta mampu memberikan kita rasa moral. Hal ini berkaitan dengan aspek moral, sehingga terkait dengan kecerdasan spiritual yang dimiliki oleh seseorang. Seseorang dengan kecerdasan spiritual yang tinggi, diharapkan mempunyai rasa moral yang baik dan mampu membedakan antara

11 R. Eckersley, "Spirituality, Progress, Meaning, and Values", Journal of Spirituality, Leadership, and Management, Vol. 7, No. 1 (2002): 15-28.

12 D. P. Ashmos \& D. Duchon, "Spirituality at Work : A Conceptualization and Measure", Journal of Management Inguiry, Vol. 8, No. 2 (2000): 134-145.

13 D.W. Mc Cormic, "Spirituality and Management", Journal of Managerial Psychology, Vol. 9, No. 6 (1994): 5-8. 
perbuatan buruk dan yang baik serta bagaimana dia harus bersikap terhadap sesamanya sesuai nilai moral yang dimilikinya.

Dengan demikian penulis berkesimpulan bahwa spiritualitas menjadi "pusat aktifitas" setiap manusia. Segala prilaku pada akhimya harus dipersepsikan sebagai serpihan spiritualitas, baik maupun jahat. Hanya saja, evaluasi baik dan jahat itu dengan sendirinya akan terkontaminasi oleh prilaku sosiologis suatu masyarakat, sehingga serpihan spiritual akan mengerucut dan mengumpul dalam kehidupan manusia. Maka, yang baik di suatu tempat tertentu belum tentu baik di tempat lain, lantaran semua ini historis dan sosiologis manusia memiliki serpihan "pengalaman suci" yang berbeda-beda pula.

Tetapi dalam kajian kelimuan, sains pun tidak mampu berdiri sendiri. Sains tetap membutuhkan instrumen-instrumen, antara lain "asal yang kelihatan" atau yang luar biasa. terdapat dua instrumen yang lazim digunakan pada global spiritual ini yang sate bersifat kolektif serta lainnya bersifat privasi. yang bersifat kolektif itu bagi suku, rakyat, peradaban, atau tradisi ialah instrumen wahyu yang terdapat dalam teks kudus, sedangkan bagi rakyat yang tidak kenal baca tulis (primitif), instrumen yang dipergunakan adalah mitos yang termuat pada legendalegenda mereka. Apabila seorang dibesarkan dalam tradisi tulis baca yang mengajarkan ilustrasi antropomorfis yang kuasa yang berasal berasal teks-teks suci, beliau pasti menganggap kebenaran menjadi sesuatu yang ada berasal pemahaman alam bawah sadarnya wacana teladan-teladan spiritual. Ini terjadi karena di akhimya petualangan manusia, ternyata roh (dimensi Ilahiyah yang terdapat dalam diri manusia) dan yang tidak terbatas (dimensi ilahi yang yang ada pada finalitas transpersonal tuhan) merupakan identik. ${ }^{14}$

Dimensi roh berfungsi secara optimal, meskipun kita mendapati tubuh yang kasar, kepribadian kemanusiaan, hubungan serta tanggung jawab yang sama seperti sebelumnya, bepergian atau kebiasaan ini sudah berobah secara dramatis, kesadaran sebagai lensa mendapati tuhan memandang global fisik sebagai akibatnya "kita" menjadi mats yang melaluinya tuhan "melihat" sebagai akibatnya dewa melihat, maka penglihatan kita merupakan penglihatan dewa. dalam perumpamaan ini terkandung esensi tasawuf. Kisah tentang turunnya setiap jiwa kedalam

${ }^{14}$ Baca, M. Montgomery, "Our Spirits, Ourselves: The Relationships between Spiritual Intelligence, SelfCompassion, and Life Satisfaction", (Disertasi---Faculty of the California School of Professional Psychology San Francisco Campus Alliant International University, 2013). 
eksistensi, pengalamannya dalam penderitaan yang diakibatkan sang perpisahan asal keberadaannya yang sejati. ${ }^{15}$

Maka makna hidup manusia menggunakan demikian terletak pada tingkat spiritualitas yang dimilikinya. terdapat sebagian manusia beropini bahwa yang dicapai pada proses pembinaan spiritualitas tadi itulah ilahi yang sebenarnya. Bahkan menjadi tenaga peggerak buat membentangkan celah dari masa kemudian ke masa depan adalah bagian asal proses yang berlangsung selama milyaran tahun dan masih berlangsung hingga kini. Perencanaan alama semesta artinya menyadari akan pengaruh pada penyingkapan penciptaan. Jika perubahan kuantum pada kesedaran semacam itu benar-sahih terjadi, itu akan mewakili kemenangan heroik atas determinisme, bukan atas alam, melainkan akan batasan-batasan pikiran sendiri yang mencegah buat bekerja secara selaras menggunakan alam semesta.

\section{Urgensi Pembinaan Kecerdasan Spiritual dalam Keluarga}

Keluarga adalah institusi pendidikan primer serta pertama bagi anak. Karen anak buat pertama kalinya mengenal pendidikan didalam lingkungan keluarga sebelum mengenal warga yang lebih lugs. Disamping itu keluarga dikatakan sebagai peletak pondasi buat pendidikan selanjutnya. Pendidikan yang diterima anak pada keluarga inilah yang akan digunakan sang anak menjadi dasar buat mengikuti pendidikan selanjutnya disekolah. Orang tua menjadi pendidik primer dan utama bagi anak artinya penanggung jawab penuh terhadap pendidikan anak-anaknya. Tugas dan tanggung jawab orang tua pada keluarga terhadap pendidikan anak-anaknya lebih bersifat pembentukan watak, agama serta spiritualnya.

Secara psikososiologi keluarga berfungsi sebagai: 1) Pemberi rasa aman bagi anak dan anggota keluarga lainya; 2) Memberi pemenuhan kebutuhan baik fisik juga psikis; 3) Asal kasih sayang serta penerimaan;

${ }^{15}$ Sejak jiwa menerima bentuk fisiknya, kenangan akan lingkungan samawi tempat beliau dari menjadi kabur, yang teringat hanyalah hal-hal yang terjadi di diri semenjak dilahirkan. Namun pengetahuan yang hilang tentang alam semesta permanen tersimpan di alam bawah sadar. Seperti pakar arkeologi yang mengorekkorek melalui berlapis-lapis batuan, bisa diketahui kembali pengetahuan itu dengan memperdalam dan memperluas kesadaran melalui shalat, meditasi, dan pemujaan. bisa dirasakan bagaimana pencerahan sebelum lahir ketika kita melihat cahaya pada seseorang bayi. Montgomery, "Our Spirits, Ourselves: The Relationships between Spiritual Intelligence, SelfCompassion, and Life Satisfaction", (Disertasi----Faculty of the California School of Professional Psychology San Francisco Campus Alliant International University, 2013). 
4) Model pola perilaku yang tepat bagi anak buat belajar menjadi anggota masyarakat yang baik; 5) Pemberi bimbingan bagi pengembangan sikap yang secara sosial dianggap tepat; 6) Pembentuk anak pada memecahkan problem yang dihadapinya pada rangka menyesuaikan dirinya terhadap kehidupan; 7) Pemberi bimbingan dalam belajar keterampilan motorik, mulut dan sosial yang dibutuhkan buat penyesuaian diri; 8) Stimulator bagi pengembangan kemampuan anak buat mencapai prestasi, baik disekolah juga pada warga; 9) Pembimbing pada membuatkan aspirasi; 10) sumber persahabatan atau sahabat bermain bagi anak hingga cukup usia buat mendapatkankan sahabat Di luar tempat tinggal, atau bila persahabatan Di luar rumah tidak memungkinkan. ${ }^{16}$

Sedangkan dari sudut pandang sosiologis, fungsi keluarga dapat diklasifikasikan kedalam fungsi-fungsi berikut : Pertama, fungsi biologis, artinya keluarga merupakan tempat memenuhi semua kebutuhan biologis keluarga seperti; sandang, pangan dan sebagainya. Kedua, fungsi ekonomis, maksudnya dikeluargalah tempat orang tua untuk memenuhi semua kewajibanya selaku kepala keluarga. Ketiga, fungsi pendidikan, dimana dikeluargalah tempat dimulainya pendidikan semua anggota keluarga. Keempat, fungsi sosisalisasi, maksudnya keluarga merupakan buaian atau penyemaian bagi masyarakat masa depan. Kelima, fungsi perlindungan, keluarga merupakan tempat perlindungan semua keluarga dari semua gangguan dan ancaman. Keenam, fungsi rekreatif, keluarga merupakan pusat dari kenyamanan dan hiburan bagi semua anggota keluarganya. Ketujuh, fungsi agama, maksudnya keluarga merupakan tempat penanaman agama bagi keluarga. ${ }^{17}$

Spiritual menjadi pengalaman holistik ialah jati diri yang mendasar bagi manusia, yang menuntun kejalan hayati yang tidak ambigu, fans serta paraksal. namun sekarang kemajuan teknologi dan sains yang betulbenar memanjakan kebutuhan material mengakibatkan manusia gagal mencapai puncak spiritual. semua itu disebabkan sang hilangnya makna

16 Ary Ginanjar Agustian, Rahasia Sukses Membangun Kecerdasan Emosi dan Spiritual ESQ (Jakarta: Arga, 2001), xxxviii.

${ }^{17}$ Beberapa faktor yang memilih kecerdasan spiritual seorang. Di antaranya sumber kecerdasan itu sendiri (God-spot), potensi qalbu (hati nurani) serta kehendak nafsu. Ketiga hal ini perlu dikaji lebih jauh sebab manusia dimanapun di global ini selalu merindukan zenit keagungan yang ditandai dengan segala dimensi eksistensinya; yaitu korelasi yang harmonis antara dewa, manusia serta alam lebih kurang. Spiritual artinya jalan yang paling ideal yang menyampaikan makna hidup bagi insan di antara makhluk Allah yang lain. Baca, Japar, "Religiousity, Spirituality and Adolescents Self-Adjustment. International Education Studies, Vol. 7, No. 10 (2014). 
filosofis serta religius dari manusia dalam menjaga ekuilibrium dialektis antara dirinya, dewa serta alam. Akibatnya mereka tersesat di medannya sediri dan hampa dalam menjalani hidup yang sedang dilaluinya.

Sebagaimana yang sudah dikemukakan sebelumnya, bahwa seseorang ahli syaraf berasal California University yaitu V.S. Ramachandran sudah berhasil menemukan keberadaan God-spot pada otak manusia, yang artinya pusat spiritual terletak antara jaringan saraf dan otak. ${ }^{18}$ Sebab God-spot ialah sentra spiritual, maka dia pada pandang sebagai faktor penentu. God-spot pada samping sebagai penentu spiritual, maka dia ditinjau menjadi somber soars hati manusia. bunyi hati tadi selalu menganjurkan agar selalu berbuat sinkron aturan yang telah ditetapkan Allah serta meninggalkan segala kemungkaran dan kejahatan. Manusia sudah dibekali sang Allah menggunakan fitrah Islam yaitu menggunakan memberikan pada hati mereka iman yang yakin. Bukti adanya perjanjian ini ialah adanya fitrah iman pada fitrah manusia. Suara hati manusia merupakan bunyi tuhan yang terekam di dalam, setiap jiwa setiap manusia. sebagai akibatnya Jika manusia berbuat tidak baik, maka suara hatinya akan menasehatinya. Andai saja masih dilakukan hal yang tidak baik tersebut beliau sempurna akan menyesal. ${ }^{19}$

Selain itu, menggali potensi qalbu. Secara klasik seringkali dihubungkan dengan polemos, amarah, ego, cinta dan logos pengetahuan. Padahal dimensi qalbu tidak hanya mencakup atau dicakup dengan restriksi katagori yang pasti. Menangkap serta memahami pengertian qalbu secara utuh artinya kemustahilan. Itu hanyalah menjadi asumsi dari proses perenungan yang sangat personal hukuman alam didalam qalbu terdapat potensi yang sangat multi dimensional. Di antaranya adalah sebagai berikut:

Pertama, Fu'ad. Artinya potensi qalbu yang sangat berkaitan menggunakan indrawi, mengolah informasi yang acapkali dilambangkan berada pada otak manusia (fungsi rasional kognitif). Fu'ad mempunyai tanggung jawab intelektual yang jujur kepada apa yang dilihatnya.

\footnotetext{
${ }^{18}$ Ibid.

${ }^{19}$ Petuah yang dikeluarkan suara hati membuat manusia selalu pada keadaan sahih. Ini ialah adalah realisasi asal kecerdasan spiritual. Kekuatan yang dibangun pada jiwa artinya manifestasi dari god-spot sebagai indikasi bahwa manusia merupakan "bagian" asal yang kuasa itu sendiri, artinya tidak mungkin ada pemisah antara yang kuasa serta manusia. God-spot artinya kendali kehidupan manusia secara spiritual, buat itu god-spot serta suara hati adalah bagian penting manusia yang mesti dipertahankan. Lihat, Eckersley, "Spirituality, Progress, Meaning, and Values", Journal of Spirituality, Leadership, and Management, Vol. 7, No. 1 (2002).
} 
Potensi ini cenderung serta selalu merujuk di objektifitas, kejujuran, dan jauh dari sikap kebohongan. Fu'ad bisa mendapatkan berita serta menganalisisnya sedemikian rupa sebagai akibatnya diperoleh pelajaran asal berita tersebut. Fu'ad yang bersikap amanah dan objektif akan selalu haws menggunakan kebenaran serta bertindak alas acum yang benar jua. Qalbu diberi potensi pikir yaitu hati dalam bentuk Fu'ad. Kemampuan buat mengolah, menentukan dan menetapkan segala isu yang dibawa sang sentuhan indra. Fu'ad memberi ruang buat akal, berpikir, bertafakur, memilih dan memilah semua data yang masuk dalam qalbu. sehingga lahirlah ilmu pengetahuan yang bermuatan moral. Pengawas setia sang Fu'ad ialah logika, zikir, pendengaran serta penglihatan yang secara konkret yang sistimatis diuraikan dalam AlQur'an. Fungsi akal adalah membantu $F u$ 'ad buat menangkap seluruh fenomena yang bersifat lahir,wujud, serta nyata dengan mempergunakan fungsi nazhar indra penglihatan. ${ }^{20}$

Kedua, Shadr. Shadr berperan buat mencicipi dan menghayati atau, memiliki fungsi emosi (marsh, benci, cinta, indah, efektif). Shadr adalah dinding hati yang mendapatkan limpahan cahaya keindahan, sehingga mampu menerjemahkan segala sesuatu serumit apapun sebagai indah dari karyanya. Shadr artinya pelita prang-prang yang berilmu. Shadr memiliki potensi besar buat hasrat, kemauan, niat, kebenaran, serta keberanian yang sama besarnya menggunakan keberanian buat menerima kejahatan serta kemunafikan. Di dalam ini pula tersimpan rasa cemas dan takut, berbeda dengan Fu'ad yang berorientasi kedepan. Shadr memandang pada masa lalu, kesejarahan, Serta nostalgia melalui rasa, pengalaman dan keberhasilan sebagai cermin. Dengan kompetensinya untuk melihat dunia masa lalu, manusia mempunyai kemampuan untuk menimbang, membanding dan menghasilkan kearifan.

Ketiga, Hawa. Potensi qalbu yang mengarahkan kemauan. di dalamnya terdapat ambisi, kekuasaan, imbas, serta harapan buat mendunia. Potensi Hawa cendrung buat membumi dan merasakan nikmat global yang bersifat fans. Fitrah manusia yang dimuliakan Allah, akhirnya tergelincir menjadi hina dikarenakan manusia tetap terpikat di global. Potensi Hawa selalu ingin membawa di perilaku-sikap yang rendah, menarik hati, merayu dan menyesatkan namun sekaligus memikat. Walaupun cahaya pada pada qalbu pada fitrahnya selalu benderang, namun sebab manusia mempunyai Hawa ini, maka semua qalbu mampu rusak binasa karena keterpikatan serta bisikan yang dihembuskan setae kedalam potensi semua $\mathrm{Hawa}^{21}$ Berasal penjelasan

${ }^{20}$ Ibid., 96.

${ }^{21}$ Ibid., 104.

El-Banat Vol. 9. No.2 (2019) 229 
ini, maka Fu'ad serta Shadr mempunyai tugas berat buat mengatasi kekuatan Hawa yang selalu membawa kearah kebinasaan serta kehancuran sebagai akibatnya lenyaplah kenikmatan yang abadi serta tak pernah mati yaitu keabadian disisi dewa yang Maha Esa. sebagai penentu nasib setiap makhluk. Hawa sebenarnya pula harus dipertahankan dalam hidup manusia, karena berfungsi sebagai energi penggerak kehidupan manusia.

Selanjutnya, penulis akan mengungkapkan ada dua faktor utama yang mempengaruhi kecerdasan secara umum yaitu: ${ }^{22}$ Pertama, faktor genetik/ bawaan. Faktor ini lebih artinya potensi kecerdasan yang sudah ada atau terberikan karena terkait menggunakan saraf-saraf yang terdapat di organ otak. Bagaimana kecepatan otak mengola atau memproses masukan yang didapat amat tergantung di syarat dan kematangan organ penting yang satu ini. Bila organ dalamnya baik, maka proses pengolahan apapun yang diterima otak akan ditangkap menggunakan baik serta dijalankan tubuh sesuai perintah otak. Hasilnya? Apa yang di kerjakan anak akan memberi akibat terbaik.

Kedua, faktor lingkungan. Kapasitas atau potensi kecerdasan yang sudah terberikan pada diri setiap anak tidak akan berarti apa-apa jika lingkungan sama sekali tak berperan dalam merangsang serta mengasah potensi tersebut. pada sini ada empat faktor lingkungan yang dapat mengasah potensi anak yaitu lingkungan rumah. Lingkungan keluarga adalah faktor pendukung terpenting bagi kecerdasan anak. dalam lingkungan keluarga anak menghabiskan waktu pada masa perkembangannya. impak lingkungan tempat tinggal ini berkaitan juga dengan persoalan stimulus. buat menjadikan anak cerdas, faktor stimulus sebagai sangat penting, baik yang berkaitan menggunakan fisik maupun mental/emosi anak. Orang tua dapat menyampaikan stimulus semenjak anak masih pada kandungan, waktu lahir, sampai dia tumbuh besar. Tentu saja menggunakan intensitas dan bentuk stimulasi yang pula pada setiap termin perkembangan. contohnya saat masih pada kandungan, stimulus lebih diarahkan di pendengaran memakai irama musik serta tuturan mak dan ayah. sehabis anak lahir, stimulus ini diperluas menjadi pada kelima indra maupun sensori-motoriknya. Begitu stimulasi lainya yang bisa merangsang dan mengembangkan kemampuan kognisinya juga kemampuan lain.

Ketiga, kecukupan nutrisi. Kiprah nutrisi bagi kecerdasan anak tidak mampu diabaikan begitu saja. buat mengakibatkan anak sehat

22 Dedeh Kurniasih, "Arti Sehat dan Bahagia, Bagi Anak", dalam http://www.tabloid-nakita.com/khasanah/khasanah06309-01.htm. Diakses pada 29 September 2019. 
secara fisik serta mental, sebetulnya perlu persiapan jauh-jauh hari sebelum proses kehamilan terjadi. Tepatnya mesti dimulai saat masa perencanaan kehamilan, sepanjang masa kehamilan serta akan terns berlanjut selama masa pertumbuhan anak. Mengapa demikian? tak lain karena kecukupan nutrisi berkaitan erat menggunakan perkembangan organ otak serta kegunaannya yang akan menentukan kualitas anak dimasa depan. Tanga nutrisi yang baik dimasa-masa sebelumnya, kemungkinan besar pertumbuhan dan fungsi otak terhambat sebagai akibatnya potensi kecerdasan anak menjadi rendah. Begitu pula kesehatannya secara holistik.

Tubuh yang lemah dan sering sakit-sakitan tentu saja juga menghipnotis potensi kecerdasannya. Interfensi dini. Akibat interfensi dini terhadap anak akan baik Jika itu dilakukan berdasarkan pertimbangan tingkat kematangannya. Menyediakan berbagai macam fasilitas bagi kepentingan anak merupakan galat satu bentuk interfensi orang tua. supaya efeknya selalu positif, ingatlah selalu buat menginterfensi anak menggunakan hal-hal kreatif. contohnya mengajak membuat mainan beserta guns merangsang kognisi anak. Yang pasti kecerdasan dalam diri anak tidak muncul begitu saja. Di luar potensi yang terberikan, sebetulnya cerdas jua berarti ketekunan menelaah sesuatu. Selain pendidikan yang diberikan orang tua di tempat tinggal, peran sekolah pula tak kalah besar. Boleh dikatakan sekolah ialah tempat tinggal kedua bagi anak yang memungkinkannya mentransfer pengetahuan, keterampilan, dan nilai-nilai kehidupan.

\section{Signifikansi Pembinaan Kecerdasan Spiritual Anak}

Temuan modern secara ilmiah yang digagas Danah Zohar dan Ian Marshall, masing-masing asal Harvard University dan Oxford University mengambarkan secara ilmiah kecerdasan spiritual. Kemudian penelitian yang lain pula mengambarkan, pertama riset pakar psikologi atau sharaf Michael Persinger di athun baru 1990-an serta lebih mutakhir lagi tahun 1997 sang pakar sharaf V.S. Ramachanran serta timnya berasal California University yang menemukan God Spot pada otak manusia. ${ }^{23}$ Langkahlangkah yang ditawarkan oleh Ary Ginanjar dapat dilakukan untuk mengembangkan Emotional Spiritual Question (ESQ) adalah sebagai berikut:

Pertama, Zero Mind Process, yaitu berusaha mengungkap belenggu-belenggu pikiran dan mencoba mengidentifikasi paradigma itu, sehingga bisa dikenali apakah kerangka berpikir tersebut sudah

${ }^{23}$ Ginanjar, Rahasia Sukses Membangun Kecerdasan Emosi dan Spiritual ESQ, 105-106. 
mengkerangkeng pikiran. Bila hal itu ads diharapkan bisa diantisipasi lebih dini sebelum menghujam kedalam benak. hasil yang diharapkan merupakan lahirnya alam pikiran jernih serta kudus yang dinamakan God Spot atau fitrah yaitu kembali pada hati serta pikiran yang bersifat merdeka serta bebas berasal belenggu. tahap ini merupakan titik tolak asal sebuah kecerdasan emosi. Disinilah tanah yang subur, kawasan buat menanam benih berupa gagasan. Penulis berpendapat bahwa setiap diri harus menguasai hati dan pikirannya sendiri. Kebebasan berfikir dan perasaan yang netral dari dirinya mesti ada, karena akal dan hati itulah hakikat dari manusia. Tidak bernilai seseorang bila ia hanya potret atau jelmaan diri orang lain. Kebebasan dan kemerdekaan ini diharapkan melahirkan prinsip hidup yang kuat. ${ }^{24}$

Kedua, mental building, maksudnya ialah kesehatan mental, yaitu terhindarnya asal gejala gangguan jiwa dan dad tanda-tanda penyakit jiwa. Pengetahuan dan perbuatan yang bertujuan buat mengembangkan segala potensi, bakat serta pembawaan semaksimal mungkin, sebagai akibatnya mampu membawa kebahagiaan diri serta orang lain. Ketiga, personal strength, intinya hal ini dimulai dari penetapan-penetapan kecil pribadi, dilanjutkan menggunakan pembentukan karakter, pengendalian diri, serta mempertahankan komitmen eksklusif. Keempat, social strength, yaitu pembentukan dan pelatihan buat melakukan aliansi, sinergi menggunakan orang lain atau menggunakan lingkungan sosialnya. Suatu perwujudan tanggung jawab sosial seseorang individu yang telah mempunyai ketangguhan pribadi. Kelima, aplikasi total, pada tahap ini seluruh langkah-langkah di atas hares dilakukan sehingga dapat diharapkan lahirnya ketangguhan sosial (Social Strength). ${ }^{25}$

Spiritualitas merupakan dasar bagi tumbuhnya harga diri, nilainilai, serta moral. Spiritualitas memberi arti di kehidupan. hayati menjadi indah dan menggairahkan karena diri manusia tidak hanya pada kurung oleh batas-batas fisik. Karen jiwa anak-anak intuitif dan terbuka secara alami, maka orang tua serta pengajar hendaknya selalu memupuk spiritualitas anaknya, cumber keceriaan serta makna hayati. Caranya menggunakan melalui perkataan, tindakan, dan perhatian sepenuhnya asal orang tua.

Di samping upaya yang dilakukan di atas, maka ada beberapa langkahlangkah untuk menumbuh dan mengembangkan kecerdasan spiritual anak yaitu sebagai berikut: Pertama, menjadi "pribadi spiritual" yang baik. Orang tua atau guru yang bermaksud mengembangkan SQ

${ }^{24}$ Ibid., 106.

${ }^{25}$ Zakiah Darajad, Kesehatan Mental (Jakarta: Toko Gunung Agung, 2001), 5. 
anak haruslah seseorang yang sudah mengalami kesadaran spiritual juga. la sudah "mengakses" sumber-sumber spiritual untuk mengembangkan dirinya. Seperti yang telah penulis jelaskan di atas, yakni ciri orang yang cerdas secara spiritual, ia harus dapat merasakan kehadiran dan pecan Tuhan dalam hidupnya. "Spiritual intelligence ia the faculty of our nonmaterial dimension the human soul," itulah ungkapan Khalil Khavari, ia harus sudah menemukan makan hidupnya dan mengalami hidup yang bermakna. la tampak pada orang-orang di sekitarnya sebagai "orang yang berjalan dengan membawa cahaya. ${ }^{26}$

Kedua, membantu anak untuk merumuskan hidupnya. Nyatakan kepada anak bahwa ada berbagai tingkat tujuan dalam merumuskan "misi" hidup ini. Mulai dari tujuan paling dekat sampai tujuan paling jauh dan bahkan tujuan akhir kita. Rumusan ini bisa di lakukan dengan menggunakan teknik "what then, senor", kita dapat membantu anak untuk menemukan misinya dengan ungkapan, jika kamu sudah sekolah kamu mau jadi apa? Aku man jadi orang pintar. Jika sudah pintar mau jadi apa? What then? Dengan kepintaranku, An akan memperoleh pekedaan yang bagus. Jika sudah dapat pekerjaan, mau jadi apa? Aku akan punya duit banyak. Jika sudah punya duit banyak, man apa? Aku login bantu orang miskin, yang di negeri kita sudah tidak terhitung jumlahnya. Sampai disini kita sudah membantu anak untuk menemukan tujuan hidupnya, hingga sampai ke tujuan akhirnya yaitu bahagia dunia dan akhirat.

Ketiga, mengajarkan al-Qur'an bersama-sama dan jelaskan maknanya dalam kehidupan kita. Dalam mengajarkan Al-Qur'an, para orang tua, juru dakwah dan para pendidik hendaknya mendasarkan pengajaranya kepada Al-Qur'an dan hadits yang berisi petunjuk-petunjuk penting Rasulullak SAW. Sebab yang akan diajarkan adalah firman Ilahi yang merupakan "undang-undang" dan pedoman hidup umat manusia. Kitab yang tidak menyimpan sedikitpun kebatilan. Kitab yang mendapat jaminan keutuhan langsung dari Dzat yang menurunkanya; Allah SWT. Kita juga patut berterima kasih kepada Allah yang telah menurunkan AlQur'an dengan bahasa Arab. Kitab yang mengandung syariat Islam serta petunjuk halal haram dan bebas dari segala macam penyimpangan, perubahan atau bahkan penggantian dengan kalimatkalimat lain, sekalipun memiliki makna yang sama. Karena Al-Qur'an berada dibawah pengawasan dan penjagaan langsung Allah SWT. Orang-orang terdahulu

${ }^{26}$ Khavari, Spiritual Intelligence; A Pratictical Guide to Personal Happiness, 109111. 
(salaf-al-ummah) banyak yang telah melaksanakan pendidikan Al-Qur'an ini untuk anak-anaknya, dan wring dilaksanakan di masjid-masjid. ${ }^{27}$

Keempat, menceritakan kisah-kisah nabi dan rasul Serta kisah teladan lainya. Anak-anak bahkan orang dewasa, sangat terpengaruh dengan cerita karena "manusia" kata Gerbner, adalah satu-satunya makhluk yang suka bercerita dan hidup berdasarkan cerita yang di percayainya. Kita tentu tidak akan pernah mampu memperoleh kepercayaan dan kaftan dari mereka kecuali jika kita telah mampu memberikan kepada mereka contoh teladan yang tinggi dan nilai-nilai yang sudah barang tentu jauh dari berbagai kesalahan dan kekhilafan. Sebaliknya, ia merupakan sosok yang cukup sempurna dan terpelihara dari kesalahan dan kekhilafan tersebut. Sosok tersebut adalah Rasulullah SAW, sebagai panutan dan teladan terbaik umat Islam semuanya.

Dalam al-Qur'an sudah dijelaskan bahwa keluarga pada hal ini orang tua bertanggung jawab terhadap pendidikan anak-anaknya. Hal ini telah tergambar pada al-Qur'an Surat at-Tahrim ayat 6 sebagaimana sudah penulis jelaskan sebelumnya. Keluarga ialah wadah pertama dan utama bagi pertumbuhan serta perkembangan anak. Jika suasana pada keluarga itu baik dan menyenangkan maka anak akan tumbuh dengan baik juga. Jika tidak, tentu akan terhambatlah pertumbuhan anak tersebut.Keluarga memiliki peranan yang sangat penting dalam upaya mengembangkan pribadi anak. Perawatan orang tua yang penuh kasih sayang dan pendidikan tentang nilai-nilai kehidupan beragama dan berrnasyarakat, merupakan faktor yang kondusif untuk mempersiapkan anak menjadi pribadi dan anggota masyarakat yang sehat.

Orang tua adalah orang yang terdekat menggunakan anak, di mana perilaku serta tingkah laku orang tua akan menjadi panutan bagi anaknya, terutama anak yang masih kecil. Pengalaman anak semasa kecil ini akan terbawa dan membekas sampai ia dewasa. dan akhirnya akan mewarnai corak kepribadianya. pada hal ini terutama sekali berasal pihak ibu lebih

${ }^{27}$ Out put dari modal pendidikan ini cukup mengagumkan. Mereka tumbuh menjadi suatu generasi yang sangat gigih mempertahankan dan menyebarkan Islam diberbagai penjuru dunia. Sejarah banyak mencatat keberhasilan mereka. Mereka yang menjadi "sings" di siang hari, tetapi dimalam hari mereka tetap ruku' dan sujud dengan penuh kekhusyukan. Ini semua karena mereka telah "menghirup" air yang memancarkan dari mats air Al-Qur'an. Dengan mempelajarinya, berarti mereka telah mempelajari ilmu pengetahuan sekaligus mempraktekkanya. Ketika Al-Qur'an suadah bersemayam di kedalaman hati mereka, dada mereka akan menjadi lapang dan tidak mudah stress, bahasa mereka lancar dan pintu-pintu samudera ilmu pengetahuan terbuka lebar untuk mereka. Baca, Khavari, Spiritual Intelligence; A Pratictical Guide to Personal Happiness, 109-111. 
dituntut buat berperan aktif, sebab maka merupakan orang yang lebih dekat menggunakan anaknya. Seorang ibu yang penuh keseriusan perhatian, penyayang serta tekun menjalankan ajaran-ajaran agama, dan untuk hidup sesuai nilai-nilai moral yang sudah digariskan sang kepercayaan, maka dia dapat membina moral dan mental (langsung) anaknya secara sehat dan teratur. ${ }^{28}$

Di dalam keluarga perlu kondisi yang mendukung pengembangan kondisi batin anak agar bisa berkhayal, berangan-angan, berbagi fantasinya, dan bermain. Permainan membuka pintu talenta serta membuat orang bebas berpikir dan dengan demikian membuatkan kecerdasan. Permainan memungkinkan anak-anak mengenal dirinya sendiri. Permainan merupakan guru terbaik bagi anak-anak. Permainan membuka pintu untuk memasuki suatu yang mungkin dirasakan seorang anak sebagai tatanan yang telah ada sebelumnya. Permainan membantu anak terhubung dengan bebas ke dunianya dan menggunakan simpel menghabiskan waktunya penuh kualitas. Kebebasan berpikir yang efektif dan positif akan berkembang dalam diri anak yang merencanakan, memulai, dan menentukan sendiri arah permainannya. Berhubungan menggunakan hal itu, sifat-sifat orang tua yang sangat mengekang atau mengendalikan anak secara positif akan merusak perkembangan SQ anak pada keluarga.

Dengan kecerdasan spiritual yang telah tertanam pada anak, maka dapat memfasilitasi dialog antara pikiran dan emosi, antara jiwa dan tubuhnya. Kecerdasan spiritual juga dapat membantu sesorang anak untuk dapat melakukan transedensi diri. Kecerdasan spiritual yang dimiliki anak merupakan kombinasi banyak faktor, meliputi kapasitas kebatinan (mysticism), transenden dan kemampuan untuk mengusahakan tingkatan yang tinggi dari kesadaran spiritual, memahami makna spiritual dalam aktivitas setiap hari, menggunakan sumber daya spiritual untuk memecahkan masalah-masalah dan menjadi berbudi pekerti yang luhur. Lebih dari itu, kecerdasan spiritual anak yang didampingi oleh orang tua, dapat mendorong visi dan tujuan hidup anak yang mencakup keseluruhan hidup dan keseluruhan alam semesta. Sehingga bimbingan dan arahan

${ }^{28}$ Ada tuntutan bagi orang tua agar selalu bisa menjadi teladan bagi anak sebab anak akan selalu belajar wacana global ini menggunakan melihat perilaku dari orang terdekatnya terutama orang tua. Anak perlu diberi waktu menggunakan kebebasan pribadinya, membenamkan diri di aktifivitas-aktivitas favoritnya seperti membaca, menatap tembok, mendengarkan musik, menari, memancing, dan sebagainya. Permainan-permainan ini membuat anak-anak produktif serta berbagi kekayaan kecerdasan dalam diri mereka. 
dalam keluarga akan menopang kesadaran diri serta penjiwaan yang mendalam untuk memahami dan mengimpementasikan kecerdasan spiritual anak dalam kehidupan sehari-hari.

\section{Kesimpulan}

Sebagai bagian penutup naskah ini penulis menyimpulkan bahwa kecerdasan spiritual adalah sesuatu yang berkaitan dengan ruh, semangat dan jiwa religius, dengan kata lain anak yang cerdas secara spiritual adalah anak yang mampu mengaktualisasikan nilai-nilai ibadah terhadap perilaku dan kegiatan dalam kehidupan sehari-hari Serta berupaya untuk mempertahankannya. Kecerdasan spiritual ini sangat penting ditanamkan kepada anak, mulai sejak anak masih kanak-kanak, bahkan sejak dalam kandungan. Di sinilah letak pentingnya orang tua terutama ibu dalam membina kecerdasan spiritual kepada anak. Faktor yang menentukan kecerdasan spiritual seseorang diantaranya adalah cumber kecerdasan itu sendiri (God-spot), potensi qalbu (hati nurani) dan kehendak nafsu. Sedangkan secara umum ada dua Faktor utama yang mempengaruhi kecerdasan yaitu: Faktor Genetik/Bawaan dan Faktor Lingkungan. Dalam membina kecerdasan spiritual kepada anak, diperlukan cara-cara yang baik dan efektif yaitu orang tua memberikan contoh teladan yang baik, memberikan kasih sayang dan perhatian penuh serta pengawasan terhadap apa-apa yang dilakukan oleh anak dalam perilakunya seharihari. Sebaliknya kurangnya perhatian orang tua akan dapat menghambat kecerdasan spiritual pada anak.

\section{Daftar Rujukan}

Agustian, Ary Ginanjar. Rahasia Sukses Membangun Kecerdasan Emosi dan Spiritual ESQ. Jakarta: Arga, 2001.

Aridhona, Julia. "Hubungan antara Kecerdasan Spiritual dan Kematangan Emosi Dengan Penyesuaian Diri Remaja", Intuisi; Jurnal Psikologi Ilmiah, Vol. 9, No. 3 (2017).

Ashmos, D. P. \& Duchon, D. "Spirituality at Work : A Conceptualization and Measure", Journal of Management Inguiry. Vol. 8, No. 2 (2000).

Buzan, Toni. Kekuatan ESQ: 10 langkah Meningkatkan Kecerdasan Emosional Spiritual, Terj. Ana Budi Kuswandani. Indonesia: Pustaka Delapratosa, 2003.

Chaplin, J.P. Kamus Lengkap Psikologi. Jakarta: Rajawali Pers, 1989. 
Darajad, Zakiah. Kesehatan Mental. Jakarta: Toko Gunung Agung, 2001.

Departemen Agama RI. Al-Qur'an dan Terjemahannya. Bandung: Syamil Cipta Media, 2005.

Eckersley, R. "Spirituality, Progress, Meaning, and Values", Journal of Spirituality, Leadership, and Management, Vol. 7, No. 1 (2002).

Japar, M. "Religiousity, Spirituality and Adolescents Self-Adjustment. International Education Studies, Vol. 7, No. 10 (2014).

Khavari, K.A. Spiritual Intelligence; A Pratictical Guide to Personal Happiness. Canada: White Mountain Publications, 2000.

King, B. "The Influence of Emotional Intelligence on the Service Performance of Casino Frontline Employees". Tourism and Hospitality Research, Vol. 11, No. 1 (2011).

Kurniasih, Dedeh "Arti Sehat dan Bahagia, Bagi Anak", dalam http://www.tabloid-nakita.com/khasanah/khasanah06309-01.htm. Diakses pada 29 September 2019.

McCormic, D.W. "Spirituality and Management". Journal of Managerial Psychology, Vol. 9, No. 6 (1994)..

Montgomery, M. "Our Spirits, Ourselves: The Relationships between Spiritual Intelligence, SelfCompassion, and Life Satisfaction". Disertasi----Faculty of the California School of Professional Psychology San Francisco Campus Alliant International University, 2013.

Nata, Abuddin. Filsafat Pendidikan Islam. Jakarta : Logos Wacana Ilmu, 1997.

Rezaei, H. A., Kazemi, N. Isfahani, “An Analysis of Spiritual Intelligence Effect on Marketing Performance and Innovation in Sales and Marketing unit (Case Study: Isfahan Mobarakeh Steel Company)". Interdisciplinary Journal of Contemporary Research in Business, Vol. 3, No. 6 (2011).

Suharto, Dedhi. Qur'anis Quotient. Jakarta : Yayasan Ukhuwah, 2003. 